\title{
Genotoxicology of Quantum Dots Used in Medical and Pharmaceutical Sciences
}

\section{Demir E*}

Unites States Food and Drug Administration, Department of Health and Human Services, National Center for Toxicological Research, Division of Genetic and Molecular Toxicology, 3900 NCTR Road, Jefferson, 72079-Arkansas, USA

Keywords: Quantum Dots (QDs); Nanomaterials; Genotoxicology; Risk assessment

\section{Introduction}

Health risk assessment of nanomaterials (NMs) is an emergent field, genotoxicity being an important endpoint to be tested. The nanotechnology industry is rapidly growing due to the interesting physicochemical properties of the new produced nanomaterials. The wide expansion of this market implies the increased presence of nanomaterials in the worldwide environment. Thus, human exposure to nanoparticles is certainly occurring at present, but a very dramatic increase is expected in the near future [1]. NMs are defined by their small size $(<100 \mathrm{~nm})$ and their novel physicochemical properties. These properties can cause new biological effects that must be studied. In addition to the general toxicological properties, the knowledge of the possible interactions of NMs with DNA is essential, due to the importance of genetic damage to human health. Genotoxic effects are linked to cancer incidence as well as to other adverse health effects, including fertility problems and genetic disorders in subsequent generations, if germinal cells are damaged. For all these reasons, extensive genotoxicity studies of NMs are required [2].

Since Quantum Dots (QDs) are increasingly used in medical and pharmaceutical sciences careful and systematic studies to determine their biosafety are needed. The semiconductors QDs constitute a generation of nanomaterials characterized by their small size (1$10 \mathrm{~nm}$ ), containing about 200-10,000 atoms, and having invaluable optical, chemical, electrical and magnetic properties [3]. They are increasingly used in medical and pharmaceutical sciences due to their high volume ratio that enable them to conjugate with multiple ligands [4] and proved to be useful in imaging probes in various tumours [5]. In spite of the interesting properties of QDs, there are doubts on their potential harmful health effects. These doubts are related to the fact that these materials contain heavy metal such as $\mathrm{Cd}, \mathrm{As}, \mathrm{Zn}, \mathrm{Pb}$, etc.

Toxic properties of QDs depend on several parameters including their composition, size, surface coating, charge, and period/route of exposure. In particular CdSe QDs have two well-known toxic elements cadmium and selenium that can produce harmful effects to many cell types. Cadmium ions $\left(\mathrm{Cd}^{2+}\right)$ are well known as probable carcinogens and can penetrate through the blood-brain barrier and placenta, accumulating in brain, liver, kidney and even in bone tissue [6]. Selenium, although is an essential nutrient for humans due it importance for many cellular processes also pose toxic potential [7] mainly above homeostatic requirements [8]. In vitro toxicity of QDs has been widely reported [9-12] including DNA damage [13].

Although in vitro physiological models can give an initial estimation of toxicity profiles, these in vitro approaches are unable to match the exact complex biological interplay taking place in vivo [14]. In this context, some in vivo studies have reported severe effect of Cd QDs exposure [15-17]. On the contrary there are some other studies showing that QDs do not cause significant toxicity in the course of longterm studies in Sprague-Dawley rats, in monkeys or in fish. Differences among studies can be associated to the composition of QDs as well to the type of shell coating, organism used or type of biomarkers used. Understanding the relative toxicities of different modes of nanoparticle exposure, as compared with their dissolved metal ions are emerging areas in ecotoxicology [17].

There is no doubt about the benefits that the use of quantum dots provides to medical and pharmaceutical sciences, which can be described as a revolution. Nevertheless, since these new materials contain heavy metals, a deep knowledge on their potential harmful effects is urgently required.

To address the molecular response to QDs exposure, should be check for potential changes of expression in different types of genes related to general stress, antioxidant protection and DNA damage response. Up-regulation of $H s p$ genes is important to counteract proteotoxic effects via chaperoning proteins during synthesis, folding, assembly and degradation and give preliminary information on the potential exposure to foreign substances. Chang, et al. [9] postulated that CdSe-core QD suppressed $H s p 90$ in human cells.

The cell guardian $p 53$ plays a key role as a hub in cellular genotoxic stress response by acting as a transcription factor to elicit cellular functions of DNA damage and repair, cell cycle arrest, and apoptosis. P53 is normally accumulated in the nucleus and converted into an active DNA-binding form to control several sets of genes to prevent the proliferation of DNA damage cells [18]. Over-expression of $p 53$ has already been observed after Drosophila larvae exposure to Cd QDs [19]. On the contrary irregular significant expression at two higher doses of $\mathrm{CdCl}_{2}$ was observed which would agree with the results observed in zebra fish [20]. In human breast MCF-7 cancer cells $\mathrm{Cd}^{2+}$ exposure results in impaired 53 functions such as conformational changes, loss of DNA binding activity, down-regulation of transcriptional activity and inhibition of gamma-radiation induced DNA damage responses [21].

\section{References}

1. Lux Report (2008) Nanomaterials state of the market: Stealth success, broad impact.

2. Singh N, Manshian B, Jenkins GJ, Griffiths SM, Williams PM, et al (2009) NanoGenotoxicology: the DNA damaging potential of engineered nanomaterials. Biomaterials 30: 3891-3914.

3. Niemeyer CM (2001) Nanoparticles, proteins, and nucleic acids: biotechnology meets materials science. Angew Chem Int Ed Engl 40: 4128-4158.

4. Geszke-Moritz M, Moritz M (2013) Quantum dots as versatile probes in medical sciences: synthesis, modification and properties. Mater Sci Eng C Mater Biol Appl 33: 1008-1021.

*Corresponding author: Esref Demir, United States Food and Drug Administration Department of Health and Human Services, National Center for Toxicological Research, Division of Genetic and Molecular Toxicology, 3900 NCTR Road, Jefferson, 72079-Arkansas, USA, Tel: 18705437667; Fax: 18705437682; E-mail Esref.Demir@fda.hhs.gov

Received April 15, 2015; Accepted May 27, 2015; Published May 30, 2015

Citation: Demir E (2015) Genotoxicology of Quantum Dots Used in Medical and Pharmaceutical Sciences. Hereditary Genet 4: 151. doi:10.4172/21611041.1000151

Copyright: (C) 2015 Demir E. This is an open-access article distributed under the terms of the Creative Commons Attribution License, which permits unrestricted use, distribution, and reproduction in any medium, provided the original author and source are credited. 
5. Mashinchian O, Johari-Ahar M, Ghaemi B, Rashidi M, Barar J, et al. (2014) Impacts of quantum dots in molecular detection and bioimaging of cancer. Bioimpacts 4: 149-166.

6. Luevano J, Damodaran C2 (2014) A review of molecular events of cadmiuminduced carcinogenesis. J Environ Pathol Toxicol Oncol 33: 183-194.

7. Zwolak I, Zaporowska H (2012) Selenium interactions and toxicity: a review. Selenium interactions and toxicity. Cell Biol Toxicol 28: 31-46.

8. Zhang H, Feng X, Chan HM, Larssen T (2014) New insights into traditional health risk assessments of mercury exposure: implications of selenium. Environ Sci Technol 48: 1206-1212.

9. Chang E, Thekkek N, Yu WW, Colvin VL, Drezek R (2006) Evaluation of quantum dot cytotoxicity based on intracellular uptake. Small 2: 1412-1417.

10. Chen N, He Y, Su Y, Li X, Huang Q, et al. (2012) The cytotoxicity of cadmiumbased quantum dots. Biomaterials 33: 1238-1244.

11. Nagy A, Steinbrück A, Gao J, Doggett N, Hollingsworth JA, et al. (2012) Comprehensive analysis of the effects of CdSe quantum dot size, surface charge, and functionalization on primary human lung cells. ACS Nano 6: 4748-4762.

12. Pathakoti K, Hwang HM, Xu H, Aguilar ZP, Wang A (2013) In vitro cytotoxicity of $\mathrm{CdSe} / \mathrm{ZnS}$ quantum dots with different surface coatings to human keratinocytes HaCaT cells. J Environ Sci (China) 25: 163-171.

13. Aye M, Di Giorgio C, Berque-Bestel I, Aime A, Pichon BP, et al. (2013) Genotoxic and mutagenic effects of lipid-coated CdSe/ZnS quantum dots. Mutat Res 750: 129-138.
14. Patri AK, Kukowska-Latallo JF, Baker JR Jr (2005) Targeted drug delivery with dendrimers: comparison of the release kinetics of covalently conjugated drug and non-covalent drug inclusion complex. Adv Drug Deliv Rev 57: 2203-2214.

15. Galeone A, Vecchio G, Malvindi MA, Brunetti V, Cingolani R, et al. (2012) In vivo assessment of CdSe-ZnS quantum dots: coating dependent bioaccumulation and genotoxicity. Nanoscale 4: 6401-6407.

16. Ambrosone A, Mattera L, Marchesano V, Quarta A, Susha AS, et al. (2012) Mechanisms underlying toxicity induced by CdTe quantum dots determined in an invertebrate model organism. Biomaterials 33: 1991-2000.

17. Jackson BP, Bugge D, Ranville JF, Chen CY (2012) Bioavailability, toxicity, and bioaccumulation of quantum dot nanoparticles to the amphipod Leptocheirus plumulosus. Environ Sci Technol 46: 5550-5556.

18. Inoue T, Wu L, Stuart J, Maki CG (2005) Control of p53 nuclear accumulation in stressed cells. FEBS Lett 579: 4978-4984.

19. Brunetti V, Chibli H, Fiammengo R, Galeone A, Malvindi MA, et al. (2013) InP/ ZnS as a safer alternative to CdSe/ZnS core/shell quantum dots: in vitro and in vivo toxicity assessment. Nanoscale 5: 307-317.

20. Tang S, Cai Q, Chibli H, Allagadda V, Nadeau JL, et al. (2013) Cadmium sulfate and CdTe-quantum dots alter DNA repair in zebrafish (Danio rerio) liver cells. Toxicol Appl Pharmacol 272: 443-452.

21. Méplan C, Mann K, Hainaut $P$ (1999) Cadmium induces conformationa modifications of wild-type p53 and suppresses p53 response to DNA damage in cultured cells. J Biol Chem 274: 31663-31670. 